\title{
PENGARUH EKSTRAK ETANOL DAUN UBI JALAR (Ipomoea batatas Lamk) SEBAGAI HEPATOPROTEKTOR TERHADAP KADAR BILIRUBIN TOTAL PADA TIKUS PUTIH JANTAN GALUR WISTAR
}

\section{(THE EFFECT OF SWEET POTATO LEAF (Ipomoea batatas Lamk.) ETHANOL EXTRACT AS HEPATOPROTECTOR TOWARD TOTAL BILIRUBIN ON WHITE MALE RATS OF WISTAR STRAIN)}

\author{
NI PUTU WINTARIANI ${ }^{\bullet}$, NI MADE DHARMA SHANTINI SUENA ${ }^{2}$ \\ ${ }^{1}$ Prodi Farmasi Klinis, Institut Ilmu Kesehatan Medika Persada Bali \\ ${ }^{2}$ Prodi D3 Farmasi, Akademi Farmasi Saraswati Denpasar \\ Denpasar-Bali
}

\begin{abstract}
Abstrak: Daun ubi jalar mengandung flavonoid dan fenol yang mampu melindungi sel-sel tubuh dari berbagai pengaruh radikal bebas. Penelitian ini bertujuan untuk mengetahui pengaruh pemberian ekstrak etanol daun Ipomoea batatas Lamk. terhadap kadar bilirubin total serum pada tikus putih galur Wistar. Penelitian ini merupakan penelitian eksperimental dengan rancangan Randomized Pre and Post Test Control Group Design. 25 ekor tikus putih jantan galur wistar dibagi menjadi 5 kelompok secara acak yaitu kelompok kontrol negatif (Aquadest + CMC Na 0,5\%), kelompok kontrol positif (hepamax dosis 46,9 $\mathrm{mg} / 200$ gramBB), kelompok perlakuan I, II dan III berturut-turut $40 \mathrm{mg} / 200$ gramBB, $80 \mathrm{mg} / 200$ gramBB, $160 \mathrm{mg} / 200$ gramBB selama 7 hari. Pada hari ke-8 seluruh kelompok diinduksi parasetamol $378 \mathrm{mg} / 200$ gramBB selanjutnya pada hari ke-10 dilakukan pengambilan darah dan pengukuran kadar bilirubin total serum. Hasil penelitian menunjukkan pemberian ekstrak etanol daun ubi jalar pada kelompok perlakuan dapat menurunkan kadar bilirubin total serum secara signifikan dengan nilai signifikansi 0,163 yaitu (p>0,05). Dosis ekstrak daun ubi jalar yang sebanding dengan hepamax 46,9 mg/200 gramBB/hari dalam menurunkan kadar bilirubin total adalah dosis $160 \mathrm{mg} / 200$ gramBB/hari. Perlu dilakukan penelitian lebih lanjut mengenai daun ubi jalar (Ipomoea batatas Lamk.) sebagai hepatoprotektor dengan jenis sediaan yang lain.

Kata kunci: hepatoprotektor, Ipomoea batatas Lamk., parasetamol.
\end{abstract}

\begin{abstract}
Sweet potato leaves contain flavonoid and phenol which can protect body cells from various effects of free radicals. The objective of this research is to identify the influence of ethanol extract of Ipomoea batatas Lamk leaf giving as hepathoprotector to serum bilirubin rate of white male rats of wistar strain. This study was an experimental research used Randomized Pre and Post Test Control Group Design. 25 white male rats of wistar strain were divided to be 5 groups randomly, they were negative control group (Aquadest + CMC Na 0.5\%), positive control group (hepamax dose $46.9 \mathrm{mg} / 200 \mathrm{gramBW}$ ), treatment groups I, II and III respectively $40 \mathrm{mg} / 200$ gramBW, $80 \mathrm{mg} / 200$ gramBW, $160 \mathrm{mg} / 200$ gramBW for 7 days. On day $8^{\text {th }}$, all group were induced paracetamol $378 \mathrm{mg} / 200 \mathrm{gramBW}$, then on day 10 were done retrieval of blood and measurement of serum bilirubin rate. Results of research indicates that ethanol extract of sweet potato leaf giving on treatment group can reduce serum total bilirubin rate with significancy value 0,163 (P <0.05). Dose of sweet potato leaf extract which is comparable with hepamax $46.9 \mathrm{mg} / 200$ gramBW/day in reducing total bilirubin rate with dose $160 \mathrm{mg} / 200$ gram BW/day. It needs to be done further research about sweet potato leaf (Ipomoea batatas Lamk.) as hepatoprotector with other preparation type.
\end{abstract}

Keywords: Ipomoea batatas Lamk., paracetamol, hepatoprotector.

•e-mail: putuwinta@gmail.com 


\section{PENDAHULUAN}

Penyakit sirosis hepar merupakan penyebab kematian terbesar setelah penyakit kardiovaskuler dan kanker. Diseluruh dunia sirosis hepar menempati urutan ketujuh penyebab kematian. Angka prevalensi penyakit sirosis hepar di Indonesia, secara pasti belum diketahui. Prevalensi penyakit sirosis hepar pada tahun 2003 di Indonesia berkisar antara 1-2,4\%. Dari ratarata prevalensi $(1,7 \%)$, diperkirakan lebih dari 7 juta penduduk Indonesia mengidap sirosis hepar (Sutadi, 2003).

Hepar merupakan salah satu organ tubuh yang berperan penting dalam proses metabolisme dan detoksifikasi berbagai bahan yang bersifat toksik menjadi kurang atau tidak toksik. Pemaparan berbagai obat-obatan dan alkohol merupakan penyebab terjadinya berbagai macam penyakit pada hepar (Tjay et al, 2007).

Mengkonsumsi obat secara berlebihan mengakibatkan kadar radikal bebas dalam tubuh menjadi berlebihan, radikal bebas ini yang memicu terjadinya stress oksidatif pada organorgan tubuh terutama hepar. Efek dari radikal bebas memang sangat membahayakan hepar, maka dari itu untuk mencegah terjadinya kerusakan hepar perlu dilakukan diet antioksidan, diet ini terbukti sangat membantu tubuh dalam menetralisir radikal bebas yang berlebihan, sehingga sangat penting untuk mengkonsumsi diet tinggi antioksidan seperti buah dan sayursayuran (Teow et al, 2006).

Kandungan antioksidan tidak hanya terdapat pada sayur dan buah-buahan, tetapi terdapat pula pada tanaman berkhasiat obat. Zaman modern seperti saat ini penggunaan tanaman berkhasiat obat masih tetap berlangsung, bahkan cenderung meningkat, disebabkan karena obat tradisional relatif murah, lebih mudah didapat, dan tidak menimbulkan efek samping bila dipergunakan secara wajar (Depkes RI, 2000).

Rumusan masalah dari penelitian ini yaitu ekstrak etanol 70\% daun ubi jalar (Ipomoea batatas Lamk.) berefek sebagai hepatoprotektor pada tikus putih jantan galur wistar dan berapa dosis yang sebanding dengan Hepamax dosis 46,9 mg/200 gram/BB pada tikus putih jantan galur Wistar.

\section{METODE PENELITIAN}

Alat Penelitian. Kandang tikus, timbangan tikus dengan spesifikasi OHAU-750S0, spektrofotometer dengan spesifikasi Thermo Scientific Genesys 840-208100 UV, sonde oral, mikro hematokrit, kapas steril, gelas piala, gelas ukur, batang pengaduk, pipet tetes, kain flannel, batang pengaduk, spatula, erlenmeyer, kompor listrik.

Bahan penelitian. Daun ubi jalar yang diambil di kebun di daerah Bandungan- Semarang pada bulan Juni 2012, parasetamol murni, aquadest, CMC Na, Hepamax, tikus putih jantan galur wistar, pakan dan minum tikus.

Metode Penelitian. Metode pembuatan ekstrak menggunakan metode maserasi yang merupakan metode ekstraksi dingin. Proses pengekstrakan simplisia dengan beberapa kali pengadukan secara berkala pada temperatur ruangan, sehingga zat-zat yang terkandung di dalam simplisia relatif lebih aman jika dibandingkan dengan penggunaan ekstraksi panas (Depkes, 1985).

Kelompok tikus dibagi menjadi 5 kelompok yaitu:

1. Kontrol negatif: Aquades + $\mathrm{CMC} \mathrm{Na}$ $0,5 \%$,

2. Kontrol positif: hepamax pada dosis 46,9 $\mathrm{mg} / 200$ gramBB

3. Perlakuan 1: ekstrak daun ubi jalar dengan dosis $40 \mathrm{mg} / 200$ gramBB

4. Perlakuan 2: ekstrak daun ubi jalar dengan dosis $80 \mathrm{mg} / 200$ gramBB.

5. Perlakuan 3: ekstrak daun ubi jalar dengan dosis $160 \mathrm{mg} / 200$ gramBB.

Data yang diperoleh dianalisis dengan SPSS 17.0 for Windows dengan taraf kepercayaan $95 \%$. Untuk mengetahui normalitas data dengan menggunakan uji Shapiro-wilk karena jumlah sampel kecil $(<50)$. Data dikatakan terdistribusi normal jika $\mathrm{p}>0,05$ dan data dikatakan tidak terdistribusi normal jika $\mathrm{p}<0,05$. Kemudian dilanjutkan dengan uji Levene's test (untuk mengetahui homogenitas data). Jika nilai $\mathrm{p}>0,05$ maka data yang diuji adalah homogen dan jika $\mathrm{p}<0,05$ maka data dikatakan tidak homogen. Jika data homogen dan terdistribusi normal, maka data dianalisa dengan statistik parametrik ANOVA satu jalan kemudian 
dilanjutkan dengan uji LSD. Apabila tidak homogen dan tidak terdistribusi normal, data dianalisa dengan statistik nonparametrik menggunakan Kruskal-Wallis kemudian dilanjutkan dengan uji Mann-Whitney (Dahlan, 2011).

\section{HASIL DAN PEMBAHASAN}

Penelitian pengaruh ekstrak etanol daun ubi jalar (Ipomoea batatas Lamk.), menggunakan hewan uji tikus putih jantan galur wistar karena beberapa organ fisiologi tikus memiliki kesamaan dengan organ fisiologi manusia dan penanganannya tidak terlalu sulit dibandingkan dengan hewan uji yang lain.

Tikus merupakan golongan binatang menyusui atau mamalia yang mempunyai kemampuan berkembang biak yang sangat tinggi sehingga sangat cocok digunakan dalam percobaan. Tikus dipilih yang berkelamin jantan, karena kondisi biologis tikus jantan relatif lebih stabil serta tidak dipengaruhi ovulasi dan hormonal seperti pada tikus betina. Tikus betina mengalami masa-masa menstruasi, kehamilan, dan masa menyusui yang tentunya akan mempengaruhi kondisi biologis tikus tersebut yang pada akhirnya akan mempengaruhi hasil penelitian.

Hewan uji yang digunakan berasal dari satu galur yaitu galur Wistar yang berumur 2-3 bulan dengan berat rata-rata 180-200 gram. Hewan uji diadaptasikan selama satu minggu serta diberi makanan dan minuman ad libitum. Hewan uji dikelompokkan menjadi 5 kelompok (kelompok negative (control), kelompok positif, kelompok perlakuan 1, kelompok perlakuan 2, kelompok perlakuan 3) dan masing-masing kelompok berisi 5 ekor tikus jantan, sebelum diberi ekstrak daun ubi jalar (Ipomoea batatas Lamk.) terlebih dahulu dilakukan pengukuran kadar bilirubin total pada masing-masing kelompok hewan uji untuk mengetahui kadar bilirubin total sebelum perlakuan (pretest) dan setelah diberi ekstrak daun ubi jalar selama 7 hari, kemudian pada hari ke-8 diinduksi menggunakan parasetamol dosis tunggal $378 \mathrm{mg} / 200$ gramBB. Penginduksian parasetamol bertujuan agar kadar bilirubin total pada tikus meningkat. Bilirubin total tikus kembali diukur setelah 48 jam sebagai data sesudah perlakuan (posttest). Kadar bilirubin total pada tikus yang diinduksi parasetamol sebelum perlakuan (pretest) berbeda dengan sesudah perlakuan (posttest), sebagaimana disajikan pada tabel 1 . berikut ini.

Tabel 1. Hasil Pengukuran Bilirubin Total Serum

\begin{tabular}{|c|c|c|c|c|}
\hline Kelompok & No & $\begin{array}{l}\text { Pretest } \\
(\mathrm{mg} / \mathrm{dl})\end{array}$ & $\begin{array}{c}\text { Posttest } \\
\text { (mg/dl) }\end{array}$ & $\begin{array}{c}\text { Selisih } \\
(\mathrm{mg} / \mathrm{dl})\end{array}$ \\
\hline \multirow{5}{*}{$\begin{array}{l}\text { Kontrol } \\
\text { Negatif } \\
\text { (kontrol) }\end{array}$} & 1 & 0,15 & 0,64 & 0,49 \\
\hline & 2 & 0,15 & 0,69 & 0,54 \\
\hline & 3 & 0,19 & 0,84 & 0,65 \\
\hline & 4 & 0,12 & 0,60 & 0,48 \\
\hline & 5 & 0,10 & 0,65 & 0,55 \\
\hline Mean \pm SD & & $\begin{array}{c}0,14 \pm 0,0 \\
3\end{array}$ & $0,69 \pm 0,10$ & $0,54 \pm-0,67$ \\
\hline \multirow{5}{*}{$\begin{array}{c}\text { Kontrol } \\
\text { Positif }\end{array}$} & 1 & 0,13 & 0,15 & 0,02 \\
\hline & 2 & 0,16 & 0,13 & $-0,03$ \\
\hline & 3 & 0,10 & 0,08 & $-0,02$ \\
\hline & 4 & 0,18 & 0,17 & $-0,01$ \\
\hline & 5 & 0,14 & 0,15 & 0,01 \\
\hline Mean \pm SD & & $\begin{array}{c}0,14 \pm 0,0 \\
3 \\
\end{array}$ & $0,14 \pm 0,03$ & - $0,006 \pm 0,021$ \\
\hline \multirow{5}{*}{ Perlakuan 1} & 1 & 0,17 & 0,38 & 0,21 \\
\hline & 2 & 0,19 & 0,38 & 0,19 \\
\hline & 3 & 0,10 & 0,37 & 0,27 \\
\hline & 4 & 0,13 & 0,34 & 0,21 \\
\hline & 5 & 0,15 & 0,40 & 0,25 \\
\hline \multirow[t]{2}{*}{ Mean \pm SD } & & $\begin{array}{c}0,15 \pm 0,0 \\
3 \\
\end{array}$ & $0,37 \pm 0,02$ & $0,23 \pm 0,03$ \\
\hline & 1 & 0,11 & 0,23 & 0,12 \\
\hline \multirow{4}{*}{ Perlakuan 2} & 2 & 0,20 & 0,27 & 0,07 \\
\hline & 3 & 0,15 & 0,24 & 0,09 \\
\hline & 4 & 0,10 & 0,22 & 0,12 \\
\hline & 5 & 0,18 & 0,29 & 0,11 \\
\hline Mean \pm SD & & $\begin{array}{c}0,15 \pm 0,0 \\
4\end{array}$ & $0,25 \pm 0,02$ & $0,10 \pm 0,02$ \\
\hline \multirow{5}{*}{ Perlakuan 3} & 1 & 0,12 & 0,13 & 0,01 \\
\hline & 2 & 0,16 & 0,19 & 0,03 \\
\hline & 3 & 0,10 & 0,09 & $-0,01$ \\
\hline & 4 & 0,15 & 0,19 & 0,04 \\
\hline & 5 & 0,15 & 0,18 & 0,03 \\
\hline \multicolumn{2}{|l|}{ Mean \pm SD } & $\begin{array}{c}0,14 \pm 0,0 \\
3\end{array}$ & $0,16 \pm 0,04$ & $0,02 \pm 0,02$ \\
\hline
\end{tabular}

Data yang diperoleh berupa selisih masing-masing kadar antara hasil pengukuran pre-test dan post-test, karena jumlah sampel $<50$ maka data dianalisis menggunakan uji Shapiro wilk untuk mengetahui apakah data terdistribusi normal atau tidak. Dilanjutkan dengan uji Levene's test untuk mengetahui homogenitas varian data. Apabila data terdistribusi normal dan 
varian datanya homogen selanjutnya dianalisa dengan menggunakan uji ANOVA.

Selisih masing-masing kadar antara pretest dan posttest menunjukkan data terdistribusi normal yaitu ( $p>0,05)$, kemudian dilanjutkan dengan uji homogenitas didapat nilai signifikansi 0,163 yaitu $(p>0,05)$. Sehingga dapat disimpulkan bahwa kelima kelompok data varian yang diperoleh terdistribusi normal dan homogen.

Masing-masing perlakuan diketahui bahwa terdistribusi normal dan homogen, maka dilanjutkan dengan analisis statistik parametrik yaitu ANAVA satu jalan. Berdasarkan hasil uji ANAVA didapatkan nilai signifikansi 0,000 $(\mathrm{p}<0,05)$ menunjukkan bahwa terdapat perbedaan yang signifikan diantara kelima perlakuan. Untuk mengetahui perlakuan mana yang memiliki perbedaan yang signifikan dilanjutkan dengan uji Post Hoc Tests dengan uji LSD, hasil uji tersebut dapat dilihat pada tabel 2 .

\section{Tabel 2. Hasil uji LSD}

\begin{tabular}{lcl}
\hline $\begin{array}{c}\text { Kelompok } \\
\text { Perlakuan }\end{array}$ & Signifikan & \multicolumn{1}{c}{ Keterangan } \\
\hline K - vs K + & 0,000 & Berbeda signifikan \\
K - vs P1 & 0,000 & Berbeda signifikan \\
K - vs P2 & 0,000 & Berbeda signifikan \\
K - vs P3 & 0,000 & Berbeda signifikan \\
K + vs P1 & 0,000 & Berbeda signifikan \\
K + vs P2 & 0,000 & Berbeda signifikan \\
K + vs P3 & 0,283 & Tidak berbeda signifikan \\
P1 vs P2 & 0,000 & Berbeda signifikan \\
P1 vs P3 & 0,000 & Berbeda signifikan \\
P2 vs P3 & 0,000 & Berbeda signifikan \\
\hline
\end{tabular}

Hasil uji LSD pada tabel 2 menunjukkan bahwa kelompok kontrol negatif (aquadest + CMC Na 0,5\%) dibandingkan dengan kelompok kontrol positif (Hepamax) serta dengan kelompok perlakuan menunjukkan signifikansi $0,000(\mathrm{p}<0,05)$ yang berarti berbeda signifikan, artinya aquadest + CMC Na 0,5\% dalam menurunkan kadar bilirubin tidak sebesar kelompok kontrol positif dan kelompok perlakuan.

Hasil uji LSD kelompok kontrol positif (Hepamax) dengan kelompok Perlakuan 1 dan kelompok Perlakuan 2 menunjukkan perbedaan yang signifikan, artinya efek dari Hepamax berbeda signifikan dengan pemberian ekstrak etanol daun ubi jalar pada dosis $40 \mathrm{mg} / 200$
gramBB dan $80 \mathrm{mg} / 200$ gramBB. Pemberian Hepamax mampu menurunkan kadar bilirubin total sampai kadar normalnya, sedangkan pemberian ekstrak etanol daun ubi jalar dosis 40 $\mathrm{mg} / 200$ gramBB dan $80 \mathrm{mg} / \mathrm{gramBB}$ dapat menurunkan kadar bilirubin total tetapi tidak sebesar dengan Hepamax.

Hasil uji LSD kelompok kontrol positif (Hepamax) dengan kelompok Perlakuan 3 menunjukkan hasil yang tidak berbeda signifikan. Ini membuktikan bahwa ekstrak etanol daun ubi jalar (Ipomoea batatas Lamk.) dosis $160 \mathrm{mg} / 200$ gramBB mempunyai potensi sebagai hepatoprotektor sebanding dengan Hepamax. Hasil statistik penelitian dapat dilihat pada lampiran 10.

Ekstrak etanol daun ubi jalar (Ipomoea batatas Lamk.) mengandung fenol dan flavonoid, karena bersifat antioksidan maka fenol dan flavonoid dapat digunakan sebagai hepatoprotektor. Parasetamol apabila dikonsumsi secara berlebihan dapat menghasilkan metabolit yaitu NAPQI (radikal bebas) yang dapat merusak sel hati sehingga kadar bilirubin total meningkat. Mekanisme kerja dari fenol dan flavonoid yaitu mengikat radikal bebas sehingga kadar bilirubin tidak meningkat (Jeffrey L, et al, 2011).

\section{SIMPULAN}

Ekstrak etanol $70 \%$ daun ubi jalar (Ipomoea batatas Lamk.) mempunyai efek sebagai hepatoprotektor pada tikus putih jantan galur wistar. Ekstrak etanol $70 \%$ daun ubi jalar (Ipomoea batatas Lamk.) pada dosis $160 \mathrm{mg} / 200$ gramBB memiliki efek sebanding dengan Hepamax dosis 46,9 mg/200 gramBB sebagai hepatoprotektor terhadap bilirubin total pada tikus jantan galur wistar setelah diinduksi parasetamol murni.

\section{DAFTAR PUSTAKA}

Dahlan, S., 2011, Statistik Untuk Kedokteran dan Kesehatan, Salemba Medika, Jakarta. 
Depkes RI, 2000, Inventaris Tanaman Obat Indonesia, jilid I, 149 - 150, Jakarta.

Depkes RI, 1985, Cara Pembuatan Simplisia, 425, Jakarta.

Jeffrey L, et al, 2011, An Analysis of $\mathrm{N}$ Acetylcysteine Treatment for Acetaminophen Overdose Using a Systems Model of Drug-Induced Liver Injury Supplementary Materials, http://jpet.aspetjournals.org.

Sutadi, S.M., 2003, Sirosis Hepatik, Universitas Sumatera Utara Digital Library, Medan.
Tjay, T.H., and Rahardja K., 2007, Obat-Obat Penting, Edisi Keenam, 318, Penerbit PT Elex Media Komputindo, Jakarta.

Teow, C.C., Truong,Van-Den, McFeeters, R.F., Thompson, R.L., Pecota, K.V., and Yencho, G.C., 2007, Antioxidant Activities Phenolic and B-carotene Contents of Sweet Potato Genotypes With Varying Flesh Colours, Disertasi, Department of Horticultural Science, NC State University, United States. 